31 Vu TK, Hung DT, Wheaton VI, Coughlin SR: Molecular cloning of a functional thrombin receptor reveals a novel proteolytic mechanism of receptor activation. Cell 1991;64:10571068 .

32 Bohm SK, Kong W, Bromme D, Smeekens SP, Anderson DC, Connolly A, Kahn ML, Nelken NA, Coughlin SR, Payan DG, Bunnett NW: Molecular cloning, expression and potential functions of the human proteinase-activated receptor-2. Biochem J 1996;314:1009-1016.

33 Ishihara H, Connolly AJ, Zeng D, Kahn ML, Zheng YW, Timmons C, Tram T, Coughlin SR: Protease-activated receptor 3 is a second thrombin receptor in humans. Nature 1997; 386:502-506.

$34 \mathrm{Xu}$ WF, Anderson H, Whitmore TE, Presnell SR, Yee DP, Ching A, Gilbert T, Davie EW, Foster DC: Cloning and characterization of human protease-activated receptor 4. Proc Natl Acad Sci USA 1998;95:6642-6646.

35 Kahn ML, Nakanishi-Matsui M, Shapiro MJ, Ishihara H, Coughlin SR: Protease-activated receptor 1 and 4 mediate activation of human platelets by thrombin. J Clin Invest 1999;103: 879-887.
36 Nystedt S, Ramarkrishnan V, Sundelin J: The proteinase-activated receptor 2 is induced by inflammatory mediators in human endothelial cells. J Biol Chem 1996;271:14910-14915.

37 Howells GL, Macey MG, Chinni C, Hou L, Fox MT, Harriott P, Stone SR: Proteinase-activated receptor-2: Expression by human neutrophils. J Cell Sci 1997;110:881-887.

38 Mari B, Guerin S, Far DF, Breitmayer JP, Belhacene N, Peyron JF, Rossi B, Auberger P: Thrombin and trypsin-induced $\mathrm{Ca}(2+)$ mobilization in human $\mathrm{T}$ cell lines through interaction with different protease-activated receptors. FASEB J 1996;10:309-316.

39 Mackie EJ, Pagel CN, Smith R, de Niese MR, Song SJ, Pike RN: Protease-activated receptors: A means of converting extracellular proteolysis into intracellular signals. IUBMB 2002;53:277-281.
40 Vliagoftis H, Befus AD, Hollenberg MD, Moqbel R: Airway epithelial cells release eosinophil survival-promoting factors (GM-CSF) after stimulation of proteinase-activated receptor 2 . J Allergy Clin Immunol 2001;107:679-685.

41 Lindner JR, Kahn ML, Coughlin SR, Sambrano GR, Schauble E, Bernstein D, Foy D, Hafezi-Moghadam A, Ley K: Delayed onset of inflammation in protease-activated receptor-2deficient mice. J Immunol 2000;165:65046510.

42 Miike S, McWilliam AS, Kita H: Trypsin induces activation and inflammatory mediator release from human eosinophils through protease-activated receptor-2. J Immunol 2001; 167:6615-6622

43 Kong Y, Chung YB, Cho SY, Kang SY: Cleavage of immunoglobulin $\mathrm{G}$ by excretory-secretory cathepsin S-like protease of Spirometra mansoni plerocercoid. Parasitology 1994;109:611621.

44 Barrett AJ, Kirschke H: Cathepsin B, cathepsin H, and cathepsin L. Methods Enzymol 1981; 80:535-561.

\title{
Announcement
}

\section{Foundation for Allergy Research in Europe - FARE}

The 12th Gold Medal FARE 2004 and two special awards FARE 2004 will be conferred during the 23rd Congress of the EAACI in Amsterdam on June 12-16, 2004.

The topic for the Gold Medal is:

Mechanisms involved in self-limitation of allergic inflammation.

The topics for the special awards are:

(1) Human allergen exposure and sensitization: Can an environmental threshold of exposure that avoids IgE-sensitization be established?

(2) Food allergy: New insights into cross-reactivity

Applications ( 10 copies together with a curriculum vitae and a list of publications) should be submitted before February 1, 2004 to:

\footnotetext{
Prof. Ronald Dahl

Department of Respiratory Diseases

Aarhus University Hospita

Norrebrogade 44, Building 2B

DK-8000 Aarhus C (Denmark)

E-mail rdahl@akh.aaa.dk
} 